\title{
ESTUDO SOBRE A NECESSIDADE RELIGIOSA DE PACIENTES EM FASE PRE-CIRÚRGICA*
}

Célia Pires de Araújo**

\section{RESUMO}

Foram estudados os problemas relativos à assistência de enfermagem quanto à necessidade religiosa de pacientes em fase précirúrgica. Para tanto, entrevistaram-se duzentos pacientes adultos, de ambos os sexos, internados em três hospitais da cidade de São Paulo, sendo um governamental $e$ dois particulares.

As entrevistas se fizeram com o auxilio de um formulário, contendo perguntas abertas, que eram preenchidas pelo pesquisador conforme respostas dadas pelos pacientes.

Conseguiu-se dessa maneira reforçar a idéia da existência do instinto teologal no ser humano, pois quase a totalidade dos pacientes estudados acreditavam em Deus e externavam sua crença com práticas religiosas as mais diversas. Pertenciam a diferentes seitas religiosas, predominando em grande número os pacientes católicos romanos.

O temor da cirurgia foi o problema comum apresentado pelos pacientes, sendo diminuído com o exercício de práticas religiosas. Para tanto, salientou-se a importância de o serviço de enfermagem não deixar que as mesmas sofram solução de continuidade com a internação do doente, pois este foi o problema de enfermagem encontrado nesse trabalho: grande número de indivíduos não conseguiam realizar suas

* Dissertação de Mestrado apresentada à Escola de Enfermagem da USP, 1976.

** Auxiliar de Ensino da Disciplina Enfermagem Cirúrgica da EEUSP. 
práticas religiosas no hospital, apresentando como razão principal desse proceder a falta de orientação.

Os pacientes ainda forneceram sugestões quanto ao que gostariam de receber do hospital para o atendimento dessa necessidade estudada. Todas as sugestões feitas poderiam ser resolvidas com o emprego do processo de enfermagem, respeitando os graus de dependência do paciente. 


\title{
STUDY ABOUT PATIENT'S RELIGIOUS NEED IN PRESURGICAL STAGE*
}

Célia Pires de Araújo**

\author{
SUMMARY
}

A study of problems related to nursing assistance of patient's religious need in presurgical stage. Two hundred adult patients of both sexes admitted in three hospitals of São Paulo were interviewed. One hospital was a governmental institution, and two were private.

Patient's interviews were made by means of a form containing open questions, which were filled out by the researcher according the patient's answers.

Therefore it was able to reinforce the existent thought of the human being having a theological instinct, for almost the totality of the studied patients believed in God and showed their beliefs with unlike religious practices. Patients belonged to different denominations, most of them roman catholics.

The common problem found among patients was the fear of surgery, which decreased with religious practices. In such a way, it was pointed out the significance of nursing service of admission, for this was the main nursing problem found in this study: large number of patients were unable to realize their practices while in hospital, given the lack of orientation the main reazon for that.

Patients also suggested what they would like to receive from the hospital to attend their religious need. All the suggestions could be solved through the application of nursing process, considering the patient's dependence degree.

* Dissertation presented to the University of São Paulo School of Nursing in Partial Fulfillment of the Requirements for the Master's Degree in Nursing.

** Assistant professor of surgical nursing of University of São Paulo School of Nursing. 